\title{
ANALISIS TREND TOPIK PENELITIAN PADA WEB OF SCIENCE DAN SINTA UNTUK PENENTUAN TEMA TUGAS AKHIR MAHASISWA
}

\author{
Bahruni $^{1}$ dan Fathurrahmad ${ }^{2}$ \\ ${ }^{1,2)}$ Manajemen Informatika, AMIK Indonesia \\ Jalan T. Nyak Arief No. 400, Jeulingke, Kota Banda Aceh, Aceh, Indonesia. \\ Email: bahruni@amikindonesia.ac.id, fathurrahmad@amikindonesia.ac.id
}

\begin{abstract}
This study aims to conduct mining using web technology to collect information data collected from Web of Science and SINTA as many as 20 each collected from 2018 to 2019. The Cross-Industrial Standard Process Methodology for data mining (CRISP-DM) is used as standard data mining processes and research methods. This research addresses research topics in the journal Web of Science and research which is accompanied by research trends and the most emerging are learning, networking, analysis, systems, control, data, images, optimization, systems, and nerves. The classification process with Generalized Linear Model and Decision Tree models has an accuracy of 94.3\%, while Gradient Boosted Trees has an accuracy percentage of 93.8\%. Naive Bayes shows an accuracy rate of 91.4\%, followed by Fast Large Margins, Deep Learning, Random Forest, and Support Vector Machine models that have an accuracy of $91.4 \%$.
\end{abstract}

Keyword : analysis, trends, research topics, web of science, sinta.

\section{PENDAHULUAN}

Sejumlah besar data saat ini dikumpulkan dan disimpan oleh organisasi, dengan harapan dapat digunakan di masa depan, hal ini menimbulkan tantangan dalam mengelola banyak data dan mengekstraksi dari pengetahuan yang tepat untuk mendukung keputusan (Amado et al, 2018). Salah satu cara untuk mengolah data dengan beragam jenis diperlukan sebuah teknik yang dikenal sebagai data mining (Mäntylä et al., 2018). Data mining merupakan proses penambangan informasi agar dapat melakukan klasifikasi dan prediksi dalam bentuk analisis data yang dapat digunakan untuk mengekstrak model yang menggambarkan kelas data penting atau untuk memprediksi tren data masa depan (Han, Pei, dan Kamber, 2011). Data mining merupakan bidang penelitian interdisipliner yang mencakup beberapa disiplin ilmu seperti database system, machine learning, intelligent information systems, statistics, dan 
expert systems (Deogun et al. 1997).

Data mining telah berkembang menjadi area penelitian yang penting dan aktif, karena tantangan teoritis dan aplikasi praktis yang terkait dengan masalah penemuan (atau penggalian) dapat menarik dimana sebelumnya tidak diketahui pengetahuan dari basis data dengan fakta dunia nyata.

Studi tentang topik penelitian dalam publikasi telah mendapatkan popularitas di bidang ilmu pengetahuan dan teknologi selama beberapa dekade karena tren baru dan topik muncul dengan cepat dan para peneliti cenderung mengandalkan saluran formal untuk mengkomunikasikan temuan penelitian (Chang, Huang, dan Lin, 2015). Evolusi topik penelitian dalam sains dan teknologi adalah hal yang menarik bagi pemerintah, industri, pendidikan dan sains.

Beberapa teknik penelitian telah dikembangkan dan digunakan di Indonesia (Liu dan Yang, 2019). Ada minat yang tumbuh dalam penelitian untuk mempelajari topik bidang Laboratory Information System (LIS), studi semacam evolusi kerangka kerja disiplin (Tuomaala et al., 2014; Wilder dan Walters, 2019), studi longitudinal dari subyek penelitian (Chang et al.,
2015; Onyancha dan Plekhanova, 2018), kategorisasi jurnal (Abrizah et al., 2015), tren yang muncul (Hou et al., 2018; Lyu et al., 2015), pola publikasi (Blecic et al., 2017), dan penelitian topik studi dalam kepustakawanan sekolah (Joo dan Cahill, 2018), kepustakawanan medis (Lyu et al., 2015), dan manajemen pengetahuan (Fteimi dan Lehner, 2016).

Meskipun para peneliti memiliki temuan yang baik di beberapa bidang, penelitian topik untuk penentuan tema tugas akhir mahasiswa masih belum tersentuh dengan investigasi lebih lanjut (Bahruni dan Fathurrahmad, 2019). Pada penelitian ini, peneliti melakukan pengelompokan dengan kata kunci dan analisis untuk tahun-tahun terakhir yang dipilih dari daftar Web of Science dan SINTA.

Penulis menyajikan dengan jelas gambaran penelitian yang diilustrasikan dengan analisis topik komparatif dan studi longitudinal pada kategori tema tugas akhir yang nantinya dipilih artikel jurnal sesuai dengan topik terkait dengan ilmu sistem informasi manajemen (Bahruni dan Fathurrahmad, 2019). Melalui analisis tersebut, penulis berharap dapat mengukur tren topik penelitian dalam literatur saat ini dan berharap untuk mendapatkan penelitian 
lebih lanjut tentang tren di bidang sistem informasi manajemen.

Penelitian ini mencoba untuk melakukan penambangan dengan menggunakan teknologi web untuk mengumpulkan data informasi yang berasal dari Web of Science dan SINTA yang dikumpulkan. Dengan demikian, dengan mengamati perkembangan topik manajemen sistem informasi di dunia dan di Indonesia menggunakan Data mining dapat membawa kontribusi yang cukup besar bagi lembaga pendidikan, dalam upaya peningkatan kurikulum dan mata kuliah pada AMIK Indonesia diharapkan hasil data mining dapat menjadikan referensi dalam penentuan tema tugas akhir dan mata kuliah baru sesuai trend teknologi saat ini. Tujuan penelitian ini adalah memberikan sebuah
Penunjang keputusan bagi pengambil kebijakan di program studi khususnya pada AMIK Indonesia agar setiap judul tugas akhir mahasiswa yang diajukan sesuai dengan trend topik yang terdapat pada Web of Science dan SINTA.

\section{METODE}

A. Kerangka Pemrosesan Text mining Peneliti mengembangkan kerangka kerja khusus yang terinspirasi oleh desain kerangka yang diusulkan oleh (Salloum et al, 2017) dan (Zhang et al., 2015). Tiga langkah termasuk dalam text mining: text preprocessing, text mining operations, dan post processing. Text preprocessing terdiri dari proses: data selection, classification, feature extraction dan text normalization,

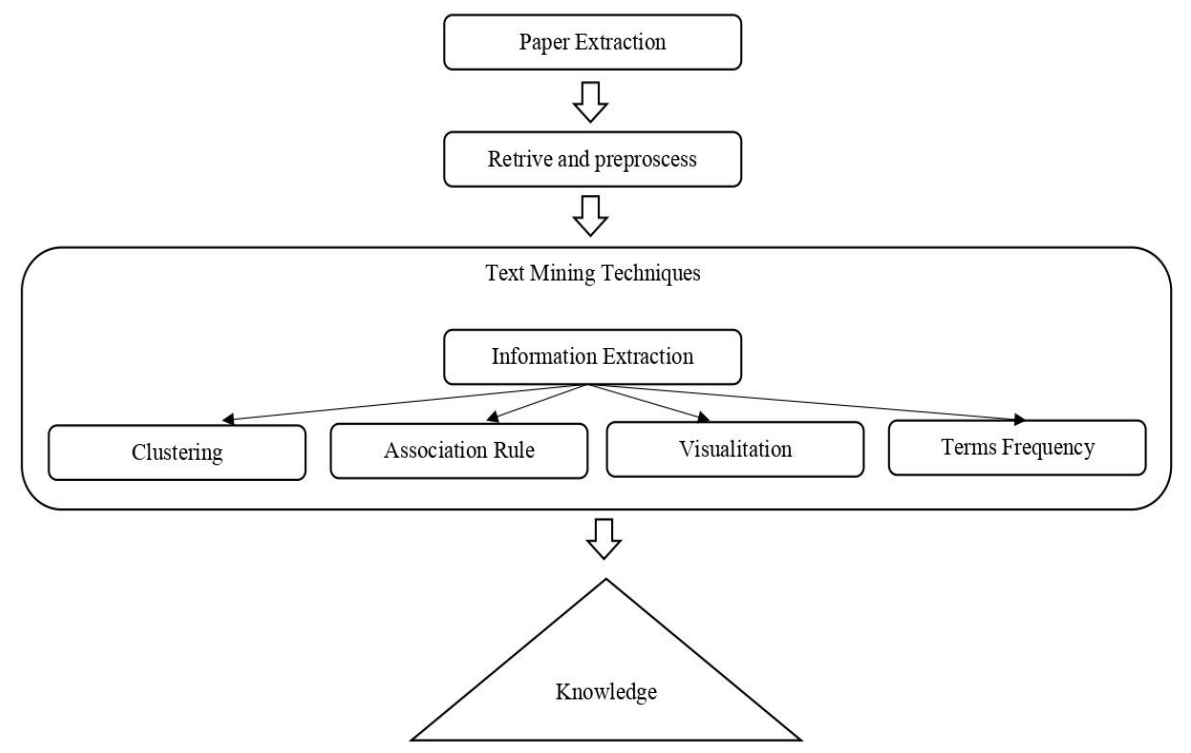

Gambar 1. Kerangka Pemrosesan Text Mining 
yaitu mengubah dokumen menjadi bentuk perantara untuk memastikan kompatibilitas berbagai alat penambangan.

$$
\text { Langkah kedua yang }
$$
dilakukan berkaitan dengan yaitu, clustering, association rule detection, visualization, dan terms frequency. Langkah ketiga dilakukan apabila adanya perubahan pada data melalui fungsi penambangan teks seperti evaluasi analisis dan visualisasi dari hasil proses yang ditampilkan.

B. Data Collection dan Pre-processing Artikel-artikel penelitian dikumpulkan dari dua database ilmiah, yaitu: Web of Science dan SINTA. Berdasarkan itu, ada 38.162 publikasi yang berhasil diambil di Web-Science-defined kategori Ilmu Komputer dan Sistem Informasi dan 230 diambil dari website SINTA. Artikel-artikel ini dikategorikan ke dalam dua folder, setiap folder mewakili basis data di mana artikel diambil. Penulis hanya mengambil 20 Jurnal dengan H-Index Tertinggi di Web of Science Core Collection sedangkan pada SINTA, penulis juga mengambil 20 Jurnal dengan rangking SINTA 1 dan 2 seperti terlihat pada Tabel 1 .

Pengambilan jurnal tersebut diambil mengingat bahwa jurnal dengan rangking SINTA 1 dan 2 merupakan jurnal nasional yang telah terindeks dan bereputasi internasional (Arjuna, 2019).

Ada dua jenis kata kunci yang tersedia di dataset, termasuk Author keywords dan Keyword Plus. Menurut Clarivate Pedoman Analytics (2018), Keyword Plus dihasilkan dari judul dari artikel yang dikutip oleh algoritma Web of Science, bermaksud untuk menambah kata kunci tradisional. Namun, kata kunci jenis ini tidak sesuai untuk penelitian karena istilah yang dihasilkan oleh algoritma juga luas untuk mencerminkan topik tertentu. Misalnya, keyword plus berisi kata kunci seperti Informasi, Model, Sistem, Manajemen, Komputer, dan sebagainya.

Tabel 1. Jurnal Ilmiah Dipilih untuk Penelitian ini

\begin{tabular}{|l|l|l|}
\hline No & Nama Jurnal & Indexing \\
\hline 1 & Bioinformatics & $\begin{array}{l}\text { Web of } \\
\text { Science } \\
\text { index }\end{array}$ \\
\hline 2 & $\begin{array}{l}\text { IEEE Transactions on } \\
\text { Pattern Analysis and }\end{array}$ & $\begin{array}{l}\text { Web of } \\
\text { Science }\end{array}$ \\
\hline
\end{tabular}




\begin{tabular}{|c|c|c|}
\hline & Machine Intelligence & index \\
\hline 3 & $\begin{array}{l}\text { IEEE Transactions on } \\
\text { Automatic Control }\end{array}$ & $\begin{array}{l}\text { Web of } \\
\text { Science } \\
\text { index }\end{array}$ \\
\hline 4 & $\begin{array}{l}\text { IEEE Transactions on } \\
\text { Information Theory }\end{array}$ & $\begin{array}{l}\text { Web of } \\
\text { Science } \\
\text { index }\end{array}$ \\
\hline 5 & $\begin{array}{l}\text { IEEE Transactions on } \\
\text { Image Processing }\end{array}$ & $\begin{array}{l}\text { Web of } \\
\text { Science } \\
\text { index }\end{array}$ \\
\hline 6 & $\begin{array}{l}\text { IEEE Transactions on } \\
\text { Signal Processing }\end{array}$ & $\begin{array}{l}\text { Web of } \\
\text { Science } \\
\text { index }\end{array}$ \\
\hline 7 & $\begin{array}{l}\text { IEEE Transactions on } \\
\text { Industrial Electronics }\end{array}$ & $\begin{array}{l}\text { Web of } \\
\text { Science } \\
\text { index }\end{array}$ \\
\hline 8 & $\begin{array}{ll}\text { IEEE Journal on } \\
\text { Selected Areas in } \\
\text { Communications }\end{array}$ & $\begin{array}{l}\text { Web of } \\
\text { Science } \\
\text { index }\end{array}$ \\
\hline 9 & $\begin{array}{ll}\text { Journal of } \\
\text { Computational } \\
\text { Physics }\end{array}$ & $\begin{array}{l}\text { Web of } \\
\text { Science } \\
\text { index }\end{array}$ \\
\hline 10 & $\begin{array}{l}\text { IEEE } \\
\text { Communications } \\
\text { Magazine }\end{array}$ & $\begin{array}{l}\text { Web of } \\
\text { Science } \\
\text { index }\end{array}$ \\
\hline 11 & $\begin{array}{l}\text { MIS Quarterly } \\
\text { Management } \\
\text { Information Systems }\end{array}$ & $\begin{array}{l}\text { Web of } \\
\text { Science } \\
\text { index }\end{array}$ \\
\hline 12 & $\begin{array}{l}\text { IEEE Transactions on } \\
\text { Medical Imaging }\end{array}$ & $\begin{array}{l}\text { Web of } \\
\text { Science } \\
\text { index }\end{array}$ \\
\hline 13 & $\begin{array}{l}\text { Expert Systems with } \\
\text { Applications }\end{array}$ & $\begin{array}{l}\text { Web of } \\
\text { Science } \\
\text { index }\end{array}$ \\
\hline 14 & $\begin{array}{l}\text { IEEE Transactions on } \\
\text { Wireless } \\
\text { Communications }\end{array}$ & $\begin{array}{l}\text { Web of } \\
\text { Science } \\
\text { index }\end{array}$ \\
\hline 15 & BMC Bioinformatics & $\begin{array}{l}\text { Web of } \\
\text { Science } \\
\text { index }\end{array}$ \\
\hline 16 & $\begin{array}{l}\text { IEEE Transactions on } \\
\text { Neural Networks and } \\
\text { Learning Systems }\end{array}$ & $\begin{array}{l}\text { Web of } \\
\text { Science } \\
\text { index }\end{array}$ \\
\hline 17 & ACM Transactions & Web of \\
\hline
\end{tabular}

\begin{tabular}{|c|c|c|}
\hline & on Graphics & $\begin{array}{l}\text { Science } \\
\text { index }\end{array}$ \\
\hline 18 & Pattern Recognition & $\begin{array}{l}\text { Web of } \\
\text { Science } \\
\text { index }\end{array}$ \\
\hline 19 & $\begin{array}{l}\text { International Journal } \\
\text { of Computer Vision }\end{array}$ & $\begin{array}{l}\text { Web of } \\
\text { Science } \\
\text { index }\end{array}$ \\
\hline 20 & $\begin{array}{l}\text { IEEE Transactions on } \\
\text { Fuzzy Systems }\end{array}$ & $\begin{array}{l}\text { Web of } \\
\text { Science } \\
\text { index }\end{array}$ \\
\hline 21 & $\begin{array}{lr}\text { International Journal } \\
\text { of Electrical and } \\
\text { Computer } \\
\text { Engineering }\end{array}$ & $\begin{array}{l}\text { SINTA } \\
(\mathrm{S} 1)\end{array}$ \\
\hline 22 & $\begin{array}{l}\text { TELKOMNIKA } \\
\text { (Telecommunication } \\
\text { Computing } \\
\text { Electronics and } \\
\text { Control) }\end{array}$ & $\begin{array}{l}\text { SINTA } \\
(\mathrm{S} 1)\end{array}$ \\
\hline 23 & $\begin{array}{l}\text { Indonesian Journal of } \\
\text { Electrical } \\
\text { Engineering and } \\
\text { Computer Science }\end{array}$ & $\begin{array}{l}\text { SINTA } \\
(\mathrm{S} 1)\end{array}$ \\
\hline 24 & $\begin{array}{l}\text { International Journal } \\
\text { of Power Electronics } \\
\text { and Drive Systems }\end{array}$ & $\begin{array}{l}\text { SINTA } \\
(\mathrm{S} 1)\end{array}$ \\
\hline 25 & $\begin{array}{lr}\text { International } & \text { Journal } \\
\text { on } & \text { Electrical } \\
\text { Engineering } & \text { and } \\
\text { Informatics } & \\
\end{array}$ & $\begin{array}{l}\text { SINTA } \\
\text { (S1) }\end{array}$ \\
\hline 26 & \begin{tabular}{lr} 
International Journal \\
on & Advanced \\
Science, Engineering \\
and Information \\
\multicolumn{2}{l}{ Technology }
\end{tabular} & $\begin{array}{l}\text { SINTA } \\
(\mathrm{S} 1)\end{array}$ \\
\hline 27 & $\begin{array}{lr}\text { Journal } & \text { of } \\
\text { Engineering } & \text { and } \\
\text { Technological } & \\
\text { Sciences } & \end{array}$ & $\begin{array}{l}\text { SINTA } \\
(\mathrm{S} 1)\end{array}$ \\
\hline 28 & $\begin{array}{lrr}\text { Journal of } & \text { ICT } \\
\text { Research } & & \text { and } \\
\text { Applications } & \\
\end{array}$ & $\begin{array}{l}\text { SINTA } \\
(\mathrm{S} 1)\end{array}$ \\
\hline 29 & $\begin{array}{l}\text { Indonesian Journal of } \\
\text { Electrical }\end{array}$ & $\begin{array}{l}\text { SINTA } \\
\text { (S1) }\end{array}$ \\
\hline
\end{tabular}




\begin{tabular}{|c|c|c|}
\hline & $\begin{array}{ll}\text { Engineering } & \text { and } \\
\text { Informatics } & \end{array}$ & \\
\hline 30 & $\begin{array}{l}\text { Jurnal Sistem } \\
\text { Informasi (Journal of } \\
\text { Information }\end{array}$ & $\begin{array}{l}\text { SINTA } \\
\text { (S2) }\end{array}$ \\
\hline 31 & JSINBIS & $\begin{array}{l}\text { SINTA } \\
(\mathrm{S} 2)\end{array}$ \\
\hline 32 & $\begin{array}{lr}\text { Register: } & \text { Jurnal } \\
\text { Ilmiah } & \text { Teknologi } \\
\text { Sistem Informasi }\end{array}$ & $\begin{array}{l}\text { SINTA } \\
\text { (S2) }\end{array}$ \\
\hline 33 & $\begin{array}{l}\text { Jurnal Teknologi dan } \\
\text { Sistem Komputer }\end{array}$ & $\begin{array}{l}\text { SINTA } \\
\text { (S2) }\end{array}$ \\
\hline 34 & 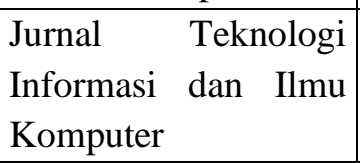 & $\begin{array}{l}\text { SINTA } \\
\text { (S2) }\end{array}$ \\
\hline 35 & $\begin{array}{l}\text { Indonesian Journal of } \\
\text { Science and } \\
\text { Technology }\end{array}$ & $\begin{array}{l}\text { SINTA } \\
\text { (S2) }\end{array}$ \\
\hline 36 & $\begin{array}{lr}\text { Lontar } & \text { Komputer: } \\
\text { Jurnal } & \text { Ilmiah } \\
\text { Teknologi } & \text { Informasi } \\
\end{array}$ & $\begin{array}{l}\text { SINTA } \\
\text { (S2) }\end{array}$ \\
\hline 37 & $\begin{array}{l}\text { Khazanah } \\
\text { Informatika: Jurnal } \\
\text { Ilmu Komputer dan } \\
\text { Informatika }\end{array}$ & $\begin{array}{l}\text { SINTA } \\
(\mathrm{S} 2)\end{array}$ \\
\hline 38 & $\begin{array}{l}\text { Journal of Degraded } \\
\text { and Mining Lands } \\
\text { Management }\end{array}$ & $\begin{array}{l}\text { SINTA } \\
\text { (S2) }\end{array}$ \\
\hline 39 & $\begin{array}{ll}\text { Indonesian } & \text { Mining } \\
\text { Journal } & \end{array}$ & $\begin{array}{l}\text { SINTA } \\
(\mathrm{S} 2)\end{array}$ \\
\hline 40 & $\begin{array}{lr}\text { Jurnal } & \text { RESTI } \\
\text { (Rekayasa Sistem dan } \\
\text { Teknologi Informasi) }\end{array}$ & $\begin{array}{l}\text { SINTA } \\
\text { (S2) }\end{array}$ \\
\hline
\end{tabular}

Oleh karena itu, peneliti hanya mengambil author keywords yang diadopsi dalam penelitian ini. Setelah melakukan ekstraksi data, penulis dapat mengekstraksi 494 kata kunci yang valid dari artikel jurnal Web of Science dan SINTA sebesar 320. Informasi dan persentase keseluruhan dari penelitian terpilih kata kunci dari dua tingkatan disajikan pada Gambar 2.

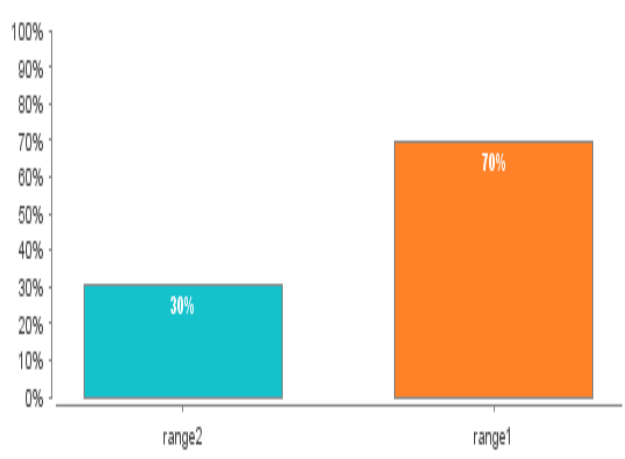

Gambar 2. Grafik dari kata kunci yang diekstraksi valid

Untuk meningkatkan kinerja dan kualitas data, semua karakteristik yang tidak relevan diblokir saat data diunggah (Gambar 1). Kerangka pemrosesan menggunakan teknik text mining sedangkan untuk mengekstrak informasi menggunakan software RapidMiner. Langkah-langkah yang digunakan untuk pemisahan dokumen menjadi token; tugas ini disebut tokenization (Verma, 2014). Langkah selanjutnya berkaitan dengan proses transformasi semua karakter dimana setiap judul dokumen dibuat dalam huruf kecil. Stop words filtering juga digunakan untuk menfilter bahasa Inggris, satu kata bahasa Inggris diperlukan 
untuk ditandai oleh setiap token. Langkah terakhir berkaitan dengan fase pemrosesan teks yang melibatkan memfilter token sesuai dengan panjangnya. jumlah minimum karakter yang harus dimiliki token adalah 4, sedangkan jumlah maksimum adalah 25 karakter.

Proses penerapan model dilakukan terhadap hasil sebelum proses yang merupakan representasi data dalam bentuk model ruang vector. Metode pertama ialah penerapan model Naive Bayes, Generalized Linear Model, Logistic Regression, Fast Large Margin, Deep Learning, Decision Tree, Random Forest, Gradient Boosted Trees, dan Support Vector Machine.

C. Alat Penelitian

Alat yang digunakan dalam penelitian ini adalah seperangkat komputer dengan spesifikasi standard. Kemudian perangkat lunak yang digunakan antara lain:

1. SQL, database dan aplikasi pemodelan Data mining.

2. Ms. Office Excel 2016,

3. Rapidminer 9.2.

4. Sistem Operasi Windows 8.1 .

\section{HASIL DAN PEMBAHASAN}

Peneliti menggunakan algoritma Naive Bayes, Generalized Linear Model, Logistic Regression, Fast Large Margin, Deep Learning, Decision Tree, Random Forest, Gradient Boosted Trees, dan Support Vector Machine yang digunakan akan membuktikan tingkat klasifikasi tren topik penelitian yang lebih baik.

A. Performance

Dari hasil cross validation maka didapatkan hasil akurasi dan klasifikasi error dari penggunaan model Naive Bayes, Generalized Linear Model, Logistic Regression, Fast Large Margin, Deep Learning, Decision Tree, Random Forest, Gradient Boosted Trees, dan Support Vector Machine sebagai berikut:

B. Akurasi

Hasil akurasi dengan menggunakan model Naive Bayes, Generalized Linear Model, Logistic Regression, Fast Large Margin, Deep Learning, Decision Tree, Random Forest, Gradient Boosted Trees, dan Support Vector Machine seperti ditunjukkan pada Gambar 3. 


\section{Accuracy}

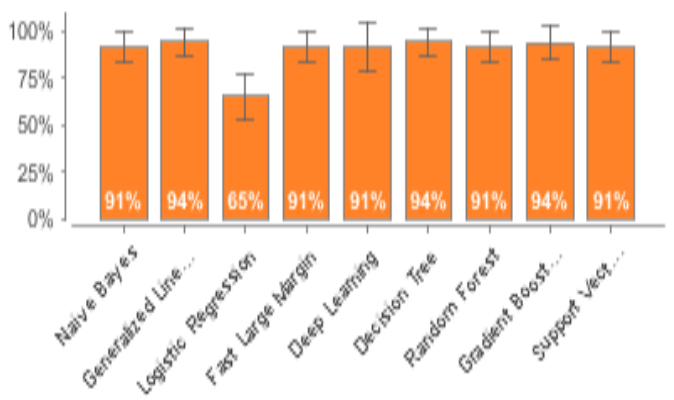

Gambar 3. Hasil Akurasi Model

Pada evaluasi akurasi, dapat diketahui keakuratan pada setiap model dan mengetahui nilai akurasi yang paling tinggi dengan membandingkan akurasi pada model. Berdasarkan hasil akurasi, model Generalized Linear Model dan Decision Tree memiliki akurasi sebesar 94.3\%, sedangkan Gradient Boosted Trees memiliki persentase akurasi sebesar 93.8\%. Naive Bayes menunjukkan tingkat akurasi sebesar 91.4\%, diikuti dengan model Fast Large Margin, Deep Learning, Random Forest, dan Support Vector Machine memiliki akurasi sebesar 91.4\%. Nilai dengan akurasi terendah menggunakan model Logistic Regression sebesar $65.2 \%$. Hal ini menunjukan bahwa tingkat akurasi tertinggi yaitu dengan menggunakan model Generalized Linear Model dan Decision Tree sehingga hasilnya dapat memprediksi cukup akurat.

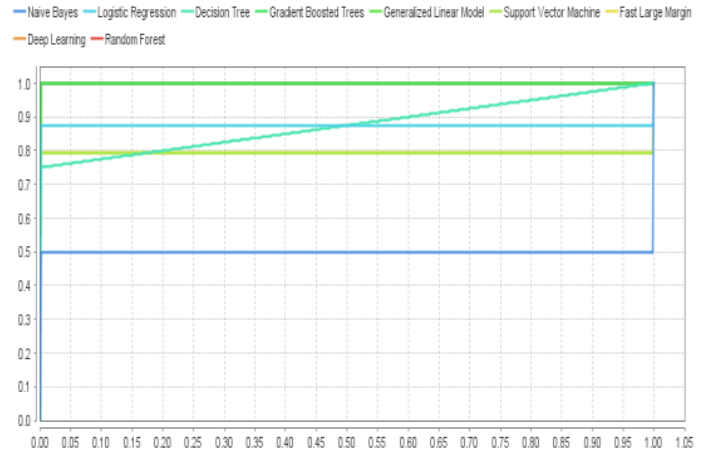

Gambar 4. Hasil ROC Comparison

Untuk tingkat classification error pada model Naive Bayes, Generalized Linear Model, Logistic Regression, Fast Large Margin, Deep Learning, Decision Tree, Random Forest, Gradient Boosted Trees, dan Support Vector Machine seperti ditunjukkan pada Gambar 5.

\section{Classification Error}

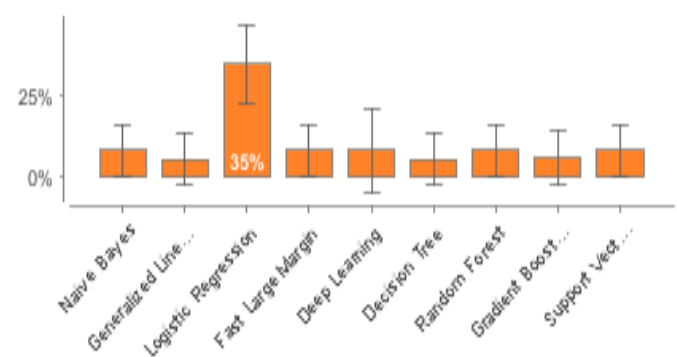

Gambar 5. Hasil Classification Error

Dari Gambar 5 dapat diketahui bahwa tingkat classification error tertinggi pada model Logistic Regression dengan persentase sebesar 34.8\%, selanjutnya pada model Naive Bayes, Fast Large Margin, Random Forest, Support Vector Machine, dan Deep Learning memiliki classification error 
sebesar 8.6\%. Gradient Boosted Trees

classification error sebesar $6.2 \%$.

Classification error terendah sebesar

5.7\% pada Generalized Linear Model dan Decision Tree.

\section{AUC}

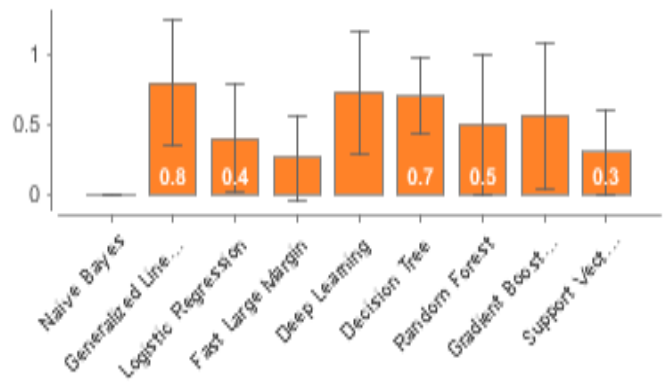

Gambar 6. Hasil AUC

Dari Gambar 6 dapat dijelaskan bahwa berdasarkan hasil AUC dengan nilai terendah pada model Naive Bayes sedangkan Support Vector Machine dengan nilai 0,300 .

\section{Precision}

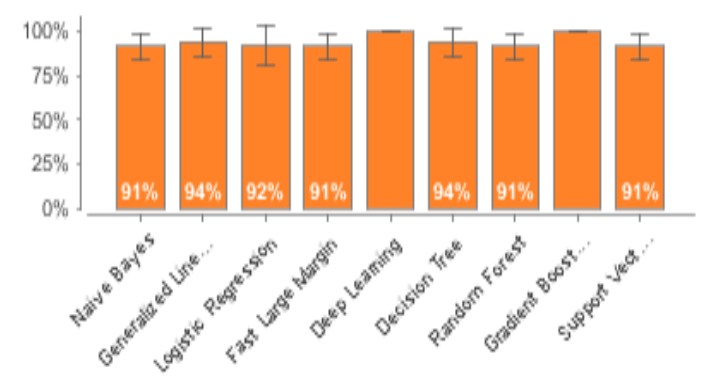

Gambar 7. Hasil Precision

Gambar 7 menunjukkan hasil precision rata-rata memiliki tinggi, dimana model Deep Learning dan Gradient Boosted Trees dengan persentase $100 \%$,
Generalized Linear Model dan Decision Tree dengan persentase $94.3 \%$, sedangkan Support Vector Machine dengan persentase $91.4 \%$.

\section{Recall}

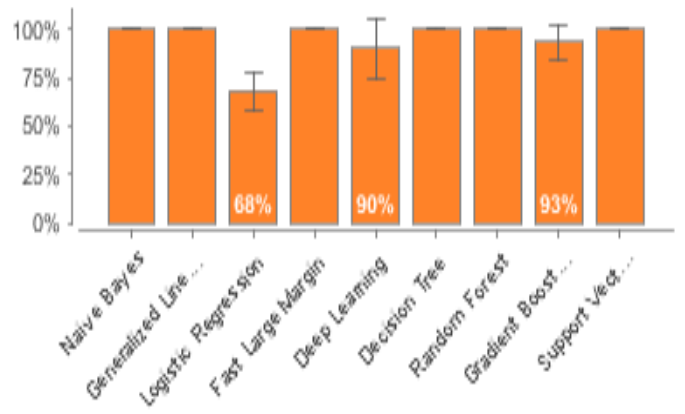

Gambar 8. Hasil Recall

Hasil dari recall menunjukkan bahwa model Naive Bayes, Generalized Linear Model, Fast Large Margin, Decision Tree, Random Forest, dan Support Vector Machine memiliki persentase sebesar 100\%, Gradient Boosted Trees 93.3\%, Deep Learning sebesar 90\%, dan Logistic Regression 68.1\%. Hasil lain seperti F Measure dan Sensitivity dapat dilihat pada Gambar 9 dan 10.

\section{F Measure}

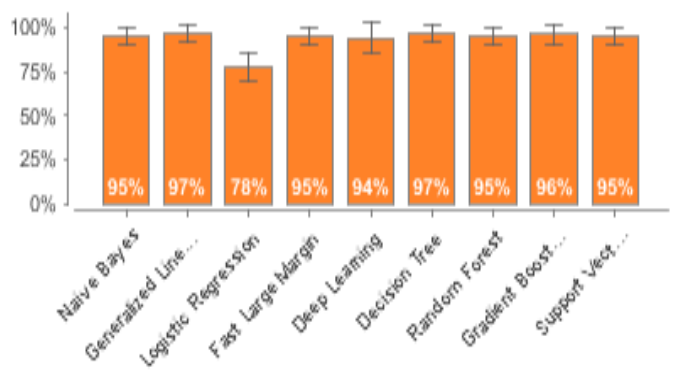

Gambar 9. F Measure 


\section{Sensitivity}

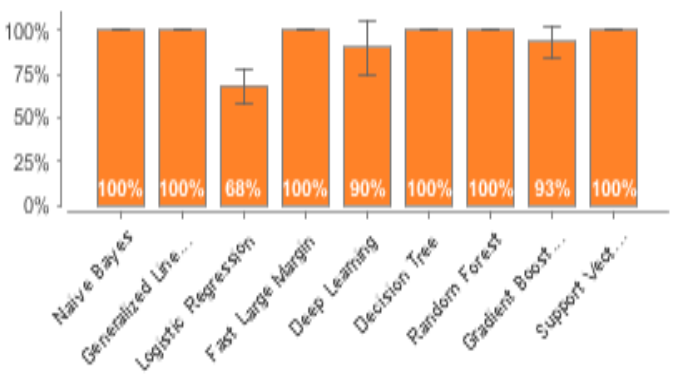

Gambar 10. Sensitivity

C. Pembahasan

Dengan menganalisis author keywords dalam jurnal Web of Science dan SINTA seperti terlihat pada tabel 1, penulis menemukan bahwa jumlah total sepuluh kata kunci teratas dalam artikel 2 (dua) jurnal range mewakili hampir $70 \%$ dan $30 \%$ dari total jumlah kata kunci dalam kategori ini. Beberapa istilah yang paling sering digunakan bahkan diindeks lebih dari 60 kali, termasuk learning 92 kali, network 60 kali, analysis 58 kali, dan system 54 kali seperti terlihat pada Gambar 11.

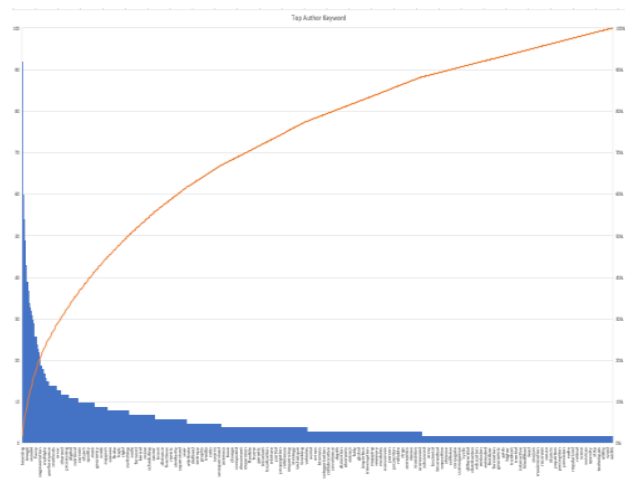

Gambar 11. Top Author keywords
Gambar 12 menunjukkan sepuluh kata kunci teratas dalam satu tahun terakhir atau volume penerbitan terakhir pada jurnal.

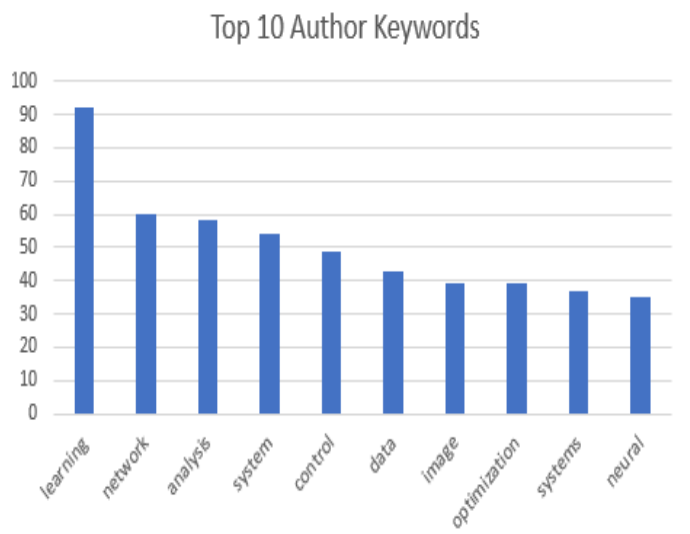

Gambar 12. Top 10 Author keywords

Temuan ini mengemukakan beberapa studi terbaru, Liu dan Yang (2019) menemukan bahwa data adalah salah satu kata kunci yang paling sering dan banyak digunakan. Kata kunci analysis dan system juga mirip dengan temuan oleh Chang et al. (2015) dan Tuomaala et al. (2014). Penelitian ini mengungkapkan beberapa istilah baru yang sedang diidentifikasi pertama kali sebagai kata kunci teratas, termasuk learning, network, analysis, system, control, data, image, optimization, systems, dan neural.

Beberapa penelitian sebelumnya kata author keywords dapat lebih rendah digunakan karena kutipan serta referensi (Chang et al., 2015; Jabeen et al., 2015; 
Onyancha dan Plekhanova, 2018).

Temuan baru membenarkan bahwa ketika metodologi yang berbeda digunakan, terutama pemilihan jurnal, hasilnya bisa berbeda dan akibatnya lebih berlaku untuk kelompok disiplin ilmu tertentu. Ini juga karena periode waktu yang dipilih untuk studi adalah yang terbaru dibandingkan dengan studi sebelumnya. Oleh karena itu, para peneliti di bidang lain dapat memahami tren topik terbaru dengan memilih penelitian popular (Liu dan Yang, 2019).

Untuk author keywords selanjutnya, penulis menemukan bahwa di kata kunci cluster based, deep leaning, model, multi, information, networks, detection, algorithm, fuzzy, dan management juga banyak digunakan.

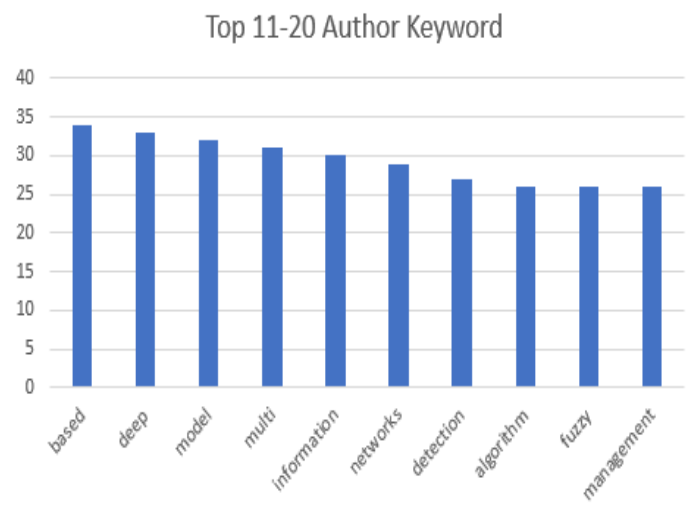

Gambar 11. Top 11-20 Author keywords

Melihat author keywords berdasarkan artikel jurnal yang dipilih Web of
Science dan SINTA maka kata kunci yang paling banyak digunakan adalah learning, network, analysis seperti ditunjukkan pada Gambar 12.

\section{TOP 10 AUTHOR KEYWORDS}

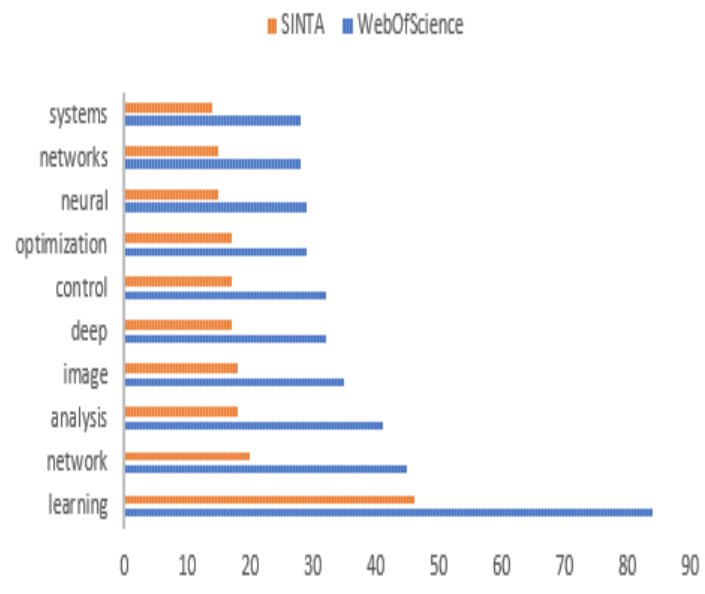

Gambar 12. Top Author keywords

\section{UCAPAN TERIMA KASIH}

Ucapan terima kasih sebesarbesarnya kepada Ditjen Penguatan Riset dan Pengembangan Kementerian Riset, Teknologi, dan Pendidikan Tinggi selaku penyandang dana penelitian pada skema Penelitian Dosen Pemula (PDP) Tahun Anggaran 2019. Tak luput pula, ucapan kepada LPPM AMIK Indonesia yang telah memberikan dukungan dan bimbingan dalam penelitian ini.

\section{DAFTAR PUSTAKA}

Abrizah, A., Noorhidawati, A. and Zainab, A.N., 2015. LIS journals categorization in the Journal Citation Report: a stated 
preference study. Scientometrics, 102(2), pp.1083-1099.

Amado, A., Cortez, P., Rita, P. dan Moro, S., 2018. Research Trends on Big Data in Marketing: A text mining and Topic Modeling Based Literature Analysis. European Research on Management and Business Economics, 24(1), pp.17.

Arjuna. 2019. Panduan Akreditasi Jurnal Nasional (ARJUNA). URL: http://arjuna.ristekdikti.go.id/.

Diakses tanggal 20 Agustus 2019 (15:19).

Bahruni, B. dan Fathurrahmad, F., 2019. Analisis Trend Topik Pengembangan Rekayasa Perangkat Lunak dalam mendukung Strategi Kurikulum Perguruan Tinggi. Jurnal JTIK (Jurnal Teknologi Informasi dan Komunikasi), 3(2), pp.70-74.

Blecic, D.D., Wiberley, S.E., De Groote, S.L., Cullars, J., Shultz, M. and Chan, V., 2017. Publication patterns of US academic librarians and libraries from 2003 to 2012.

Chang, Y., Huang, M., dan Lin, C. 2015. Evolution of Research Subjects in Library and Information Science Based on Keyword, Bibliographical Coupling, and Cocitation Analyses. Scientometrics, 105(3), 2071-2087.

Chen, F., Deng, P., Wan, J., Zhang, D., Vasilakos, A.V. dan Rong, X., 2015. Data mining for the internet of things: literature review and challenges. International Journal of Distributed Sensor Networks, 11(8), p.431047.
Clarivate Pedoman Analytics. 2018. Web of Science Core Collection: Introduction. URL: http://clarivate.libguides.com/wosc c/basics. Diakses tanggal 20 Juli 2018 (20:10).

Deogun, J.S., Raghavan, V.V., Sarkar, A. dan Sever, H., 1997. Data mining: Trends in research and development. In Rough Sets and Data mining (pp. 9-45). Springer, Boston, MA.

Fteimi, N. and Lehner, F., 2016. Main research topics in knowledge management: A content analysis of ECKM publications. Electronic Journal of Knowledge Management, 14(1).

Han, J., Pei, J. and Kamber, M., 2011. Data Mining: Concepts and Techniques. Elsevier.

Hou, J., Yang, X. and Chen, C., 2018. Emerging trends and new developments in information science: A document co-citation analysis (2009-2016). Scientometrics, 115(2), pp.869892.

Jabeen, M., Yun, L., Rafiq, M. and Jabeen, M., 2015. Research productivity of library scholars. New Library World.

Joo, S. and Cahill, M., 2018. Exploring Research Topics in the Field of School Librarianship based on Text mining. School Libraries Worldwide, 24(1).

Liu, B., 2007. Web Data mining: exploring hyperlinks, contents, and usage data. Springer Science \& Business Media. 
Liu, G. dan Yang, L., 2019. Popular Research Topics in the Recent Journal Publications of Library and Information Science. The Journal of Academic Librarianship, 45(3), pp.278-287.

Lyu, P.H., Yao, Q., Mao, J. and Zhang, S.J., 2015. Emerging medical informatics research trends detection based on MeSH terms. Informatics for Health and Social Care, 40(3), pp.210-228.

Mäntylä, M. V., Graziotin, D., dan Kuutila, M. 2018. The evolution of sentiment analysis $-A$ review of research topics, venues, and top cited papers. Computer Science Review, 27, 16-32. doi: 10.1016/j.cosrev.2017.10.002.

Onyancha, J. and Plekhanova, V., 2018. 'Noise Reduction in Web Data: A Learning Approach Based on Dynamic User Interests'. International Journal of Information and Education Technology, 12(1), pp.7-14.

Salloum, S. A., Al-Emran, M., Monem, A. A., dan Shaalan, K. (2017). Using Text mining Techniques for Extracting Information from Research Articles. Studies in Computational Intelligence, 373$397 . \quad$ doi:10.1007/978-3-31967056-0_18

Tuomaala, O., Järvelin, K., dan Vakkari, P. 2014. Evolution of library and information science, 1965-2005: Content analysis of journal articles.

Verma, T., 2014. Renu and Deepti Gaur, Tokenization and Filtering Process in RapidMiner. International Journal of Applied Information System (IJAIS).
Wilder, E.I. and Walters, W.H., 2019. Quantifying Scholarly Output: Contribution Studies and Productivity Studies in Sociology since 1970. The American Sociologist, 50(3), pp.430-436.

Zhang, Y., Chen, M. dan Liu, L., 2015, September. A review on text mining. In 2015 6th IEEE International Conference on Software Engineering and Service Science (ICSESS) (pp. 681-685). IEEE. 